\title{
Mutations in SQSTM1 encoding p62 in Amyotrophic Lateral Sclerosis: genetics and neuropathology
}

Elisa Teyssou ${ }^{1}$, Takahiro Takeda ${ }^{2}$, Vincent Lebon $^{2}$, Séverine Boillée ${ }^{1}$, Brahima Doukouré ${ }^{2}$, Guillaume Bataillon $^{2}$, Véronique Sazdovitch ${ }^{2}$, Cécile Cazeneuve ${ }^{3}$, Vincent Meininger ${ }^{4}$, Eric LeGuern ${ }^{1,3}$, François Salachas ${ }^{1,4}$, Danielle Seilhean ${ }^{1,2 \#}$ and Stéphanie Millecamps ${ }^{1 * \#}$

${ }^{1}$ INSERM UMR_S975, CNRS UMR7225, Université Pierre et Marie Curie-Sorbonne Universités; Hôpital PitiéSalpêtrière, Paris, France.

${ }^{2}$ Département de Neuropathologie, Assistance Publique Hôpitaux de Paris (AP-HP); Hôpital Pitié-Salpêtrière, Paris, France.

${ }^{3}$ Département de Génétique et Cytogénétique, APHP, Unité Fonctionnelle de neurogénétique moléculaire et cellulaire; Hôpital Pitié-Salpêtrière, Paris, France.

${ }^{4}$ Fédération des Maladies du Système Nerveux, APHP, Centre de référence maladies rares SLA; Hôpital PitiéSalpêtrière, Paris, France.

*To whom correspondence should be addressed: Dr Stéphanie Millecamps, Centre de Recherche de l'Institut du Cerveau et de la Moelle épinière, Groupe hospitalier Pitié-Salpêtrière, 83, Bd de l'Hôpital, 75013 Paris, France, tel: 33157274341, fax: 33157274795, e-mail: stephanie.millecamps@upmc.fr

\# These authors contributed equally to this work

Key words: Motor neuron disease, familial and sporadic ALS, Paget's disease, p62, neuropathology, FTLDALS.

\section{Disclosure statement}

The authors declare that they have no conflict of interest.

Protocols were approved by the Medical Research Ethics Committee of “Assistance Publique-Hôpitaux de Paris" and all participants signed a consent form for the research. 


\begin{abstract}
Mutations in SQSTM1 encoding the sequestosome 1/p62 protein have recently been identified in families with and sporadic cases of amyotrophic lateral sclerosis (ALS). p62 is a component of the ubiquitin inclusions detected in degenerating neurons in ALS patients. We sequenced SQSTM1 in 90 French patients with familial ALS (FALS) and 74 autopsied ALS cases with sporadic ALS (SALS). We identified, at the heterozygote state, one missense c.1175C>T, p.Pro392Leu (exon 8) in one of our FALS and one substitution in intron 7 (the c.1165+1G>A, previously called IVS7+1 G-A, A390X) affecting the exon 7 splicing site in one SALS. These mutations that are located in the ubiquitin-associated domain (UBA domain) of the p62 protein have already been described in Paget's disease and ALS patients carrying these mutations had both concomitant Paget's disease. However, we also identified two novel missense mutations in two SALS: the c.259A>G, p.Met87Val in exon 2 and the c.304A>G, p.Lys102Glu in exon 3. These mutations that were not detected in 360 control subjects are possibly pathogenic. Neuropathology analysis of three patients carrying SQSTM1 variants revealed the presence of large round p62 inclusions in motor neurons and immunoblot analysis showed an increased p62 and TDP-43 protein level in the spinal cord. Our results confirm that SQSTM1 gene mutations could be the cause or genetic susceptibility factor of ALS in some patients.
\end{abstract}




\section{Introduction}

Amyotrophic Lateral Sclerosis (ALS) is the most common adult onset motor neuron disease. Pathological hallmarks detected in spinal motor neurons of most ALS patients include skein like inclusions, which are positive for ubiquitin, ubiquitin-binding protein p62 (also called sequestosome 1, [38]) and TDP-43 (TAR DNAbinding protein 43, [39]), and cystatin C-positive Bunina bodies [40]. Recently, SQSTM1 encoding sequestosome 1/p62 protein (440 amino acids) was screened as a candidate gene in a large cohort of ALS patients. Ten different mutations ( 9 heterozygous missense and one deletion) were identified in 6/340 FALS $(1.8 \%)$ and 9/206 SALS (4.4\%) [14]. Following, two reports screened SQSTM1 gene in different populations. Out of 124 SALS and 170 frontotemporal lobar degeneration (FTLD) patients of Italian origin around 3\% carried the mutations and this gene was also responsible for 2/54 SALS (3.7\%) of Japanese origin [23, 44]. Although expanded hexanucleotide repeats in C9ORF72 occurring in $23-46 \%$ of FALS and $4-8 \%$ of SALS became the major genetic defects in ALS [12, 43], mutations in SQSTM1 could account for a substantial part of ALS causing genes making p62 a potential player in ALS. The aim of this study was to confirm the contribution of SQSTM1 to ALS by analyzing 164 French ALS patients (90 FALS and 74 autopsied SALS) in whom all the other ALS genes had been excluded and to analyze the neuropathological features in patients carrying SQSTM1 variants.

\section{Methods}

Genotyping. The eight coding exons with exon-intron boundaries of SQSTMI (ensembl reference sequence: ENSG00000161011) were sequenced in 90 French FALS with mean age of onset of 60 years (SE 1, range 33 to 80 years), mean disease duration of 46 months (SE 5, range 8 to 260 months, including 13 censored data) and 74 SALS French autopsied cases (30 DNA were from blood and 50 DNA were extracted from Liver slices) with mean age of onset of 61 years (SE 1, range 35 to 81 years), mean disease duration of 49 months (SE 5, range 8 to 206 months) (Table 1). Data were censored at the last date of patient visit. Control samples were obtained from sex and age-matched healthy Caucasian individuals of French background.

Initial ALS populations comprised 270 FALS with probable or definite ALS [6] including 10 autopsied cases and 80 more autopsied SALS cases (30 DNA were from blood and 50 DNA were extracted from Liver slices). Analyses of $C 9 O R F 72, S O D 1, T A R D B P, F U S, A N G, V A P B, D A O, O P T N$ and $U B Q L N 2$ genes had previously been performed [33-37]. Mutation frequencies of C9ORF72, SOD1, TARDBP and FUS have been described 
elsewhere for FALS [34]. Autopsied SALS included 3 patients with C9ORF72 expansion, 2 with SOD1 and one with TARDBP mutation.

Sequence of the primers and PCR conditions are available upon request.

Immunoblotting. Transversal sections of spinal cords were homogenized in $50 \mathrm{mM}$ Tris- $\mathrm{HCl} \mathrm{pH} 8,150 \mathrm{mM}$ $\mathrm{NaCl}$, protease inhibitors (Complete mini tablets, Roche) and $0.5 \mathrm{U} / \mu$ l Benzonase endonuclease (Merck). The samples were incubated at $37^{\circ} \mathrm{C}$ during 30 minutes. SDS was then added at a final concentration of $2 \%$. Tissue extracts were centrifuged at $13,000 \mathrm{rpm}$ for $10 \mathrm{~min}$ and protein concentration of supernatants was estimated by the bichinconinic acid assay (Sigma Aldrich). Proteins $(20 \mu \mathrm{g})$ were separated on NuPAGE ${ }^{\mathrm{TM}} 4-12 \%$ Bis-Tris Gel (Invitrogen) and electrophoretically transferred to nitrocellulose membranes. Membranes were incubated overnight with primary antibodies in PBS/ 5\% milk/ 0.1\% Tween 20, followed by one hour of incubation with appropriate peroxidase-conjugated antibodies. Signals were detected using ECL plus Western Blotting Detection System (GE Healthcare). Densitometric analysis was perfomed using Multi Gauge V3.0 (Fujifilm) software using tubulin as internal standard. For each patient, 5 measures (from 5 independent western blot analyses) were recorded for p62 and TDP-43. p62 and TDP-43 levels were compared between patients with SQSTM1 mutation and control SALS patients (with no mutation in the screened genes) using Mann Whitney test (GraphPad Prism 4 software). The significance level for all comparisons was set at 0.05 .

Primary antibodies included mouse monoclonal anti-p62 antibody raised against aminoacids 257-437 of the human protein (610833, BD Biosciences), rabbit anti-TARDBP raised against TDP-43 protein (12892-1-AP, ProteinTech) and mouse anti- $\beta$-tubulin B-5-1-2 (Sigma-Aldrich). Peroxidase-conjugated AffiniPure Goat AntiRabbit and Anti-Mouse (all with minimal cross-reaction to human proteins) were from Jackson immunoResearch Laboratories.

RT-PCR. Total RNAs were extracted from whole transverse sections (including anterior and posterior horn) of spinal cords using the Trizol reagent (Invitrogen). First-Strand cDNA synthesis was performed using ThermoScript RT-PCR system (Invitrogen) according to the manufacturer's instructions. PCR was performed with Green Taq DNA polymerase (Fermentas) and the following primers: 5'ACGTTGGGGAGAGTGTGGCAG-3' (forward primer in SQSTM1 exon 5) and 5'CCTTCATCAGAGAAGCCCATGGA-3' (reverse primer in SQSTM1 exon 8). The PCR conditions were: $95^{\circ} \mathrm{C}$, 
3 min and 25 cycles $\left(95^{\circ} \mathrm{C}, 30 \mathrm{~s}, 62^{\circ} \mathrm{C}, 30 \mathrm{~s}, 72^{\circ} \mathrm{C}, 30 \mathrm{~s}\right)$. Amplified fragments were sequenced using standard procedure.

\section{Neuropathology.}

ALS patients were enrolled in a brain donation program declared to the Ministry of Research and Universities, as requested by French Law. An explicit consent was signed by the patient himself, or by the next of kin, in the name of the patient, in accordance with the French Bioethical Laws. For each autopsied patient, the brain was weighted before fixation. Neuropathologic examination was done on the formalin-fixed half brain, the other half being kept frozen in the brain bank. On the fixed hemi-brain, 16 samples were embedded in paraffin for microscopic examination: midfrontal gyrus, motor cortex, first temporal gyrus, hippocampus, ventral amygdala, primary visual cortex, parietal cortex, orbital frontal cortex, head of the caudate nucleus, lenticular nucleus, thalamus, mesencephalon, pons, medulla oblongata, cerebellum, three levels of spinal cord (cervical, thoracic, lumbar). Slides were stained with hematoxylin-eosin or, for the spinal cord with Bodian silver impregnation associated with Luxol fast blue.

Immunostainings for p62, ubiquitin and TDP-43 were performed on three levels of the spinal cord (cervical thoracic and lumbar) and on the medulla oblongata, frontal isocortex, hippocampus and cerebellum. Immunohistochemistry for cystatin $\mathrm{C}$ was, in addition, performed on spinal cord and medulla oblongata. After deparaffinization, the $5 \mu \mathrm{m}$ thick sections were immunolabeled with the antibodies listed in Table 2 . For most antibodies, the immunostaining was performed by an automatic slide stainer (Benchmark® XT Ventana® staining system), the slides being pre-treated at $95^{\circ} \mathrm{C}$ in either $\mathrm{CC} 1(\mathrm{pH}=8)$ or $\mathrm{CC} 2(\mathrm{pH}=6)$ proprietary retrieval buffers (Ventana Medical Systems®) (Table 2). The biotinylated secondary antibody was included in the detection kit (Ventana Medical Systems Basic DAB Detection Kit 250-001®). The streptavidin-biotinperoxidase complex was revealed by diamino-benzidine. For ubiquitin immunohistochemistry, the slides were pre-treated by formic acid (FA, $80 \%$ ), for 5 to 10 minutes (Table 2). For p62 staining, the slides were microwave pretreated (450W) during 2x10 min in citrate buffer $\mathrm{pH} 6$ (Table 2).

The semi quantitative analysis of the lesions focused on anterior horn motor neurons of medulla oblongata and spinal cord in 45 autopsied ALS patients including patients with SQSTM1 (n=3), C9ORF72 (n=8), SODI (n=4), $\operatorname{TARDBP}(\mathrm{n}=2)$ mutations and other patients with no mutation in any of these genes $(\mathrm{n}=28)$.

A consensual definition based on the shape and localization of ubiquitinated inclusions (filamentous or skeinlike, large round and granular) was established by five of us (DS, TT, VL, BD, SM). The semi-quantitative 
assessment for p62 and TDP-43 in cervical, thoracic and lumbar spinal cord and in medulla oblongata was performed by three of us (TT, VL, BD) who were blinded to the genetic data, following a 4-point ordinal scale ( 0 , none; 1 , rare; 2 , moderate; 3 , severe), a similar scoring approach had been used effectively in several similar comparative pathology studies $[4,5,16,17,21]$. The score means obtained for filamentous, large round, and granular inclusions were compared between patients carrying SQSTM1, C9ORF72, SOD1 mutations and other patients with no mutation in any of these genes using ANOVA (SPSS 11.0 software). If the difference was significant $(\mathrm{p}<0.05)$, the groups were compared by pairs using a Tukey's post hoc test analysis. The patient group with mutation in TARDBP ( $\mathrm{n}=2$ patients only) was not included in this analysis.

\section{Results}

\section{Genetic analysis}

In FALS we identified, at the heterozygous state, one missense mutation in exon 8 (the c.1175C>T, p.Pro392Leu) in one patient (case 1) that presented with distal lower limb disease onset at 54 years and deceased after a 133 months disease duration (Fig. 1a, 1c). No DNA was available for other affected family members and the segregation could not be further studied (Fig. 1d). In SALS the c.1165+1G>A substitution in intron 7 presumably affecting the exon 7 splicing site (Fig. 2a) was identified in one woman who had a distal lower limb disease onset at 75 years and disease duration of 42 months (case 2). These two patients had concomitant Paget's disease (Table 3).

We also identified, at the heterozygote state, two missense mutations in two SALS patients: the c.259A $>$ G, p.Met87Val in exon 2 (carried by case 3) and the c.304A>G, p.Lys102Glu in exon 3 (carried by case 4, Fig. 1 a). The first patient (case 3) carrying a missense variant showed bulbar onset at 68 and disease duration of 18 months and the second one (case 4) started the disease at 81 years of age which lasted for 10 months (Table 3). History of Paget's disease was not recorded for these patients. These variants affect aminoacids that are highly conserved in mammals (Fig. 1b). They were not identified in the dbSNP Short Genetic Variations, the 1000 Genomes Project and the NHLBI ESP Exome Variant Server databases and in our analysis of 360 control Caucasian individuals. The sequencing of exon 7 and 8 in this control population identified one single variant, not reported previously: the c.1313C>T, p.Pro438Leu in one 60 year-old man.

To further analyse the effect of the c.1165+1G>A in the intron 7 splicing site variant (carried by case 2), we amplified the p62 cDNA sequence spanning from exons 5 to 8 (Fig. 2c) and sequenced the corresponding fragments. We found that this substitution led to the deletion of part of the exon 7 (r.1052_1165del, $\Delta$ Ex7) in the 
mRNA sequence (Fig. 2b-c) which probably results in the production of a truncated p.Gly351_Pro388del protein of 402 aminoacids as suggested by the additional band present on the western blot analysis (Fig. 2d, case 2).

Quantitative analysis of p62 (for case 2, p62 level is the sum of the two bands) and TDP-43 levels on immunoblots showed that p62 and TDP-43 protein levels were increased in the group of patients with SQSTM1 mutations compared to the control SALS group (Fig. 2e) with a significant difference reached for both stainings ( $\mathrm{p}=0.0129$ for $\mathrm{p} 62$ and $\mathrm{p}<0.0001$ for TDP-43).

\section{Neuropathology analysis}

Autopsy had been performed for 3 of the patients carrying mutations in SQSTM1 (cases 2-4).

The brain of the woman carrying the c.1165+1G>A (p.Gly351_Pro388del) mutation (case 2) weighted 1180g. Atrophy of the frontal lobe including the precentral gyrus, associated with atrophy of the anterior spinal roots was noticed. Microscopic examination of the spinal cord and medulla oblongata showed mild neuronal loss, cystastin C positive Bunina bodies, TDP-43 and p62 positive skein like and rounded inclusions and TDP-43 positive diffuse granular staining. Pronounced neuronal loss and gliosis were observed in the substantia nigra, without Lewy bodies. In the midfrontal and precentral gyri, fibrillary gliosis was associated with superficial spongiosis. Immunohistochemistry showed numerous TDP-43 positive filamentous inclusions in layer 2 , associated to thin neurites (Fig. 4a), resembling Type A pathology according to Mackenzie classification [29]. p62 immunohistochemistry showed a lower number of paranuclear inclusions, and no neurites (Fig. 4c). Despite these neuropathological observations on cortical regions, this patient had no clinical FTD (Table 3).

In the male patient with M87V mutation (case 3), the brain weighted $1345 \mathrm{~g}$ before fixation. No cerebral atrophy was noticed, macroscopic abnormalities being limited to atrophy of the anterior spinal roots. At microscopic examination, neuronal loss was severe in the anterior horns of the spinal cord. Immunochemistry showed TDP43 and p62 positive skein like and rounded inclusions, numerous TDP-43 positive granules, and cystastin C positive Bunina bodies. A mild neuronal loss was observed in the substantia nigra, without Lewy bodies. No lesion was found at supratentorial level, except diffuse A beta deposits.

In the female patient with K102E mutation (case 4), the brain weight was $1066 \mathrm{~g}$. No noticeable focal cerebral atrophy was found at macroscopic examination, contrasting with atrophy of anterior spinal roots. At microscopic examination, neuronal loss was mild in the spinal anterior horns and in the XII ${ }^{\text {th }}$ nucleus, although Bunina bodies 
were quite numerous. Immunochemistry showed ubiquitin, TDP-43 and p62 positive rounded inclusions (Fig. 3d-f, 3g-i, supplementary Fig. 1a) and cystastin C positive Bunina bodies. In addition numerous motor neurons contained intracytoplasmic small ubiquitin and TDP-43 positive granules (Fig. 3a, 3c). This pattern was not observed with p62 immunohistochemistry (supplementary Fig. 1c). In some rare neurons bigger "seed-like", p62 positive aggregates were observed (Fig. 3b). These seed-like inclusions were also seen with TDP-43 staining (supplementary Fig. 1b). A mild neuronal loss was observed in the substantia nigra without Lewy bodies. There was neither evidence of major neuronal loss in the central motor cortex nor severe degeneration of the corticospinal tracts. A mild superficial spongiosis was observed in the second layer in the midfrontal gyrus. Immunohistochemistry showed some TDP-43 positive inclusions of various shapes, either round or filamentous, spread throughout the cortex, with only a few positive neurites (Fig. 4b), resembling Type B pathology according to Mackenzie classification [29]. p62 immunohistochemistry showed a lower number of inclusions, generally rounded, and no neurites (Fig. 4d). p62 positive glial inclusions were found in both cortex and spinal cord.

The three cases showed numerous p62 and TDP-43 glial positive inclusions in spinal cord. No p62 or TDP-43 inclusion was found in the granular cells of the cerebellum for the three patients.

To determine whether there were differences in ubiquitinated inclusion pathology in cases with or without SQSTM1 variants, we examined spinal cord tissues from 45 ALS patients including the 3 SALS patients carrying SQSTM1 variants (p.Gly351_Pro388del, p.Met87Val and p.Lys102Glu corresponding to cases 2, 3 and 4, respectively), 8 patients with C9ORF72 repeat expansion, 4 patients with SOD1 mutations, 2 patients with TARDBP mutations and 28 other patients devoid of mutation in any of these genes. Several types of ubiquitinated inclusions (stained with p62 and TDP-43) were quantified for these patients (Supplementary Table 1): skein like filamentous inclusions (Fig. 3e-f), large round cytoplasmic inclusions (Fig. 3h-i) and intracytoplasmic diffuse granular aggregates (Fig. 3c). The score means obtained for large round inclusions were compared between patients carrying SQSTM1, C9ORF72, SOD1 mutations and other patients with no mutation in any of these genes using ANOVA. The patient group with mutation in TARDBP was not included in this analysis since we only had $n=2$ patients. One way ANOVA analyses between the 4 groups of patients revealed that the p62 round inclusion pathology scores were different $(\mathrm{p}=0.041)$. Tukey's post hoc test analysis for comparison of the 4 groups by pairs showed that p62 positive rounded inclusions were more numerous in ALS patients with SQSTMI variant than in patients with no mutation in the screened genes (Tukey's post hoc test, $\mathrm{p}=0.03$ ) but were not different between SQSTM1 mutation carriers and patients with mutation in another gene 
(SOD1 or C9ORF72). The lack of statistically significant difference between SQSTM1 mutation carriers and patients with C9ORF72 and SODI mutation could be due to too small sample sizes. Indeed, there was a significant difference (Mann Whitney's test, $\mathrm{p}=0.045$ ) between patients with SQSTM1 patients and all the other patients pooled together (devoid of mutation in any of the screened genes and carrying a mutation in SOD1 or C9ORF72). The number of rounded inclusions stained for TDP-43 was not statistically different between the 4 groups of patients $(\mathrm{p}=0.08)$. These semiquantitative differences in the numbers of p62 versus TDP-43-positive inclusions may simply reflect differences in the sensitivity of the antibodies employed. Occurrence of filamentous inclusions positive for p62 ( $\mathrm{p}=0.006)$ or TDP-43 $(\mathrm{p}=0.01)$ differed between the 4 groups of patients. Less TDP-43 positive filamentous inclusion was detected in the SOD1 group than in C9ORF72 (p=0.02) or SQSTM1 ( $\mathrm{p}=0.02)$ patients which is in accordance with the absence of TDP-43 immunoreactivity previously reported for patients with SOD1 mutation [28]. There was no difference in the incidence of granular inclusions stained by 662 or TDP-43 antibodies for the four groups of patients.

\section{Discussion}

Our SQSTM1 genetic analysis identified 4 variants corresponding to a frequency of $1.1 \%$ in FALS and $4 \%$ in SALS which is similar to the frequencies previously reported in FALS (1.7\%) and SALS (3-4.4\%) [14, 23, 44]. We identified two novel SQSTM1 mutations, p.Met87Val and p.Lys102Glu, which are possibly pathogenic. The mutations that we identified in intron 7 and exon 8 have already been described in patients with ALS [14] or Paget's disease of bones (PDB) [8, 31, 32]. PDB is a chronic disease of the skeleton due to focal increased bone turnover affecting 2-3\% of individuals older than 55 and 6-7\% of individuals over 85 years of age in Caucasian populations [9]. Manifestations of the disease include bone pain, enlargement, and deformities at the pagetic sites, susceptibility to fractures, deafness and neurologic complications [20]. Recent studies have confirmed that both genetic and environmental factors are implicated in its etiology [19]. Seven loci (PDB1 to 7) have been identified and mutations in SQSTM1 gene, mostly located in the c terminus region of the protein encoded by exon 7 and 8, containing the highly conserved ubiquitin binding domain (Fig. 1c), are responsible for the phenotype linked to chromosome 5q35 (PDB3). These UBA domain mutations impair the ability of p62 to bind to ubiquitin [7], probably resulting in aberrant NF- $\mathrm{B}$ signaling [19].

In France, SQSTM1 mutations represent 13\% of PDB patients [8] corresponding to an estimated frequency of $0.4 \%$ for the overall French population. This estimation is in accordance with the single variant we found 
(c.1313C > T, p.Prol438Leu) in one out of 360 control patients (mutation frequency of $0.3 \%$ ) after sequencing SQSTM1 exon 7 and 8. However, as shown in both previous studies that have analyzed patients of Caucasian origin $[14,44]$ and now in our study, the frequency of this mutation in SQSTM1 is 10 fold higher in ALS patients therefore arguing in favor of a role of SQSTM1 as a causative or a susceptibility gene in ALS.

The c.1175C>T, p.Pro392Leu has been previously detected in 2/340 FALS and 1/206 SALS but 0/737 control patients [14]. It is the recurrent mutation identified in Paget's disease patients (PDB), responsible for $46 \%$ of familial and $16 \%$ of sporadic cases of PDB in the French Canadian population [27]. In addition, mice carrying a proline to leucine mutation at codon 394 of mouse sqstm1 (P394L), corresponding to the P392L SQSTM1 mutation in humans, develop a disease similar to human PDB with focal increases in bone turnover and disruption of the normal bone architecture [11]. No obvious sign of motor neuron disease as impaired motor function or muscular atrophy has been described [11] although no study has assessed motor neuron numbers and shape in the spinal cord of this Paget's disease mouse model.

The c.1165+1G>A substitution in intron 7 affecting the exon 7 splicing was previously identified in a family of Australian descent with Paget's disease (it was called IVS7 + 1 G-A, A390X since it was thought to lead to the production of a truncated protein of 390 amino acids terminating at an inframe stop codon at position $+6-9$ within intron 7) [24]. Our results show that this mutation led to the deletion of part of exon 7 in the mRNA sequence (r.1052_1165del) and the production of a truncated p.Gly351_Pro388del protein of 402 aminoacids in the spinal cord. Both pPro392Leu and p.Gly351_Pro388del mutations have been repeatedly identified in French patients with Paget's disease [32]. In contrast to the previously reported ALS patients with SQSTMI mutations [14], both ALS patients with mutations in ubiquitin binding domain of SQSTM1 described here (i.e intron 7 for one SALS and exon 8 for one FALS) had concomitant PDB. However coexistence of these two disorders could be underestimated as PDB is often asymptomatic [20] and its diagnosis is based on radiographic findings. Coexistence of these two diseases has already been described in some patients with mutations in valosin containing protein (VCP) [25]. This gene has already been linked to Inclusion Body Myopathy with early-onset Paget's disease of the bone and Frontotemporal Dementia (IBMPFD) [47]. In addition, OPTN, another ALS causing gene [30] is also known as a susceptibility gene for PDB [2]. Interestingly SQSTM1, VCP and OPTN all encode proteins that bind to ubiquitin $[10,18,46]$. These three genes that share common functions in protein degradation pathways could confer susceptibility to Paget's disease and motor neuron disease when mutated. The clinical evaluation of bone integrity and the neuropathological assessment of motor neuron should be explored in ALS and PDB patients, respectively. In the present study, the observation of p62/TDP-43 positive 
Teyssou et al. ActaNeuropathol 2013

AcceptedManuscript

inclusions in spinal motor neurons of case 2 (with c.1165+1G>A, r.1052_1165del, p.Gly351_Pro388del mutation) coupled to the accumulation of p62/TDP-43 proteins that could be detected in the spinal cord of this patient by immunoblot analysis strongly argues in favor of a participating role of this "PDB mutation" in ALS phenotype.

p62 positive inclusions are common in many degenerative diseases including tauopathies and synucleopathies $[15,26]$ and a key features in neuropathological diagnosis and classification of ALS and FTLD, both sporadic and familial [38, 41]. The cortical pathology observed in the present study in ALS patients with SQSTM1 mutations (cases 2 and 4) confirms again the overlap between motor neuron disease and fronto-temporal lobar degeneration.

In contrast to the SQSTM1 Paget's disease linked mutations, those reported to date in ALS patients are distributed throughout the protein (Fig. 1c) suggesting that different domains of the p62 protein endowed with other functions, beside its ubiquitin binding one, could be impaired in ALS. Considering the implication of TDP43 in ALS and since p62 has been shown to bind to TDP-43 (and to be potentially involved in its degradation), another p62 function that could be impaired by the ALS causing mutations would involve disruption in TDP-43 p62 interaction, previously suggested to participate in the pathogenesis of TDP-43 proteinopathy [45]. Additional evidence have shown that overexpression of p62/SQSTM1 reduces TDP-43 aggregation in an autophagy and proteasome-dependent manner [3]. Our immunoblot findings showing concomitant accumulation of p62 and TDP-43 proteins in spinal cord of SQSTM1 mutation carriers are in line with a shared pathological effect of these two proteins.

Data from p62 deleted mice showed that p62 loss of function results in increased ubiquitin staining in hippocampus and cortex together with accumulation of insoluble ubiquitinated proteins, of hyperphosphorylated tau and neurofibrillary tangles resulting in neurodegeneration and Alzheimer-like phenotype [42]. It is therefore tempting to hypothesize that a loss of a specific function of p62 protein due to mutations in a specific domain of SQSTM1 could also result in ALS phenotypes.

Previous studies have described that the profile of p62 neuropathology can predict the underlying genetic defect in ALS and FTLD [5]. However the number of p62 positive inclusions is not necessarily correlated to the number of TDP-43 aggregates (Al Sarraj et al., 2011). In FTLD-ALS with C9ORF72 mutations, neuronal inclusions are both TDP-43 and p62 positive, except in the cerebellum were inclusions are only p62 positive [1]. In patients with SQSTM1 mutations reported here, the granular deposit of TDP-43 and ubiquitin is not positive 
for p62. These results underline that the relationship between p62 and other accumulating proteins remains largely unknown.

Our study described two novel SQSTM1 mutations identified in ALS patients which are possibly pathogenic and provided neuropathological examination of three mutation carriers. The presence of large round p62 inclusions was consistently observed in these SQSTM1 patients. In mean, there was a higher number of these round p62 inclusions in spinal cord of SQSTM1 carriers compared to the other patients although they were rare in two of the SQSTM1 cases examined. Moreover increased protein levels of p62 and TDP-43 were detected in the spinal cord extracts of SQSTM1 patients. These observations support that these SQSTM1 mutant probably contribute to the ALS phenotype. Overall our study confirmed that SQSTMI gene mutations could be the cause or a genetic susceptibility factor of the disease in some ALS patients.

\section{Acknowledgments}

We are grateful to the patients and their families. We thank the Généthon cell and DNA bank (Evry, France) and the CRicm DNA and cell bank (Paris, France) for patients' DNA and the genotyping and sequencing platform facilities of the ICM (Paris, France). This work was financed by the Association pour la Recherche sur la Sclérose latérale amyotrophique et autres maladies du motoneurone (ARSla, France), the Association française contre les myopathies (AFM, France) and the Fondation NRJ-Institut de France (France).

\section{Legends of the figures}

\section{Figure 1. SQSTM1 missense mutations identified in ALS patients.}

(a) Part of chromatograms showing the normal sequence (control), the c.259A $>$ G, p.Met87Val variant in exon 2, the c.304A>G, p.Lys102Glu in exon 3 and the c.1175C > T, p.Pro392Leu variant in exon 8 pointed by an arrow and the corresponding normal sequences (control).

(b) Sequence alignment of part of the SQSTM1 amino acids from diverse species using MultAlin website. The position of the Met87, Lys102 and Pro392 (pointed by an arrow) are in red. Sequences used include Homo sapiens (NP_003891.1), Pan troglodytes (XP_001153075.1), Bos taurus (NP_788814.1), Rattus norvegicus (NP_787037.2), Mus musculus (NP_035148.1), Gallus gallus (XP_001233249.2) and Xenopus laevis (NP_001079920.1). (c) Representation of p62 protein domains with the position of the aminoacid substitutions previously reported in Paget's disease (green), ALS (black) and FTLD (orange). Mutations reported in the present study are indicated in red. Data are compiled from [13, 14, 19, 23, 31, 44]. SH2, src homology 2 domain; 
AID, acidic interaction domain; ZZ, zinc finger region; TRAF6, tumor necrosis factor receptor-associated factor 6 binding domain; PEST, Proline, Glutamic acid, Serine, Threonine rich region; UBA, ubiquitin-associated domain. (d) Pedigree of the patient carrying the c.1175C>T, p.Pro392Leu mutation (case 1). DNA was available for the index cases only (indicated by an arrow). The age at onset, site of onset (in brackets) and age at death (in brackets) are indicated below the patients when the information was available.

Figure 2. Molecular analysis of the effect of the c.1165+1G>A mutation on SQSTM1 splicing and p62 protein expression.

Part of chromatograms showing the position of the c.1165+1G>A variant pointed by an arrow in intron 7 (a) leading to the r.1052_1165del in cDNA sequence (b) identified in one autopsied ALS case $(\Delta \mathrm{Ex} 7$, case 2$)$. Amplification of the cDNA product with primers localized in exon 5 and 8 of the SQSTM1 gene resulting in a single fragment of 514 bp in the M87V carrier (case 3), the K102E carrier (case 4) and SALS individuals and in two fragments of 514 and 410 bp in the c.1165+1G>A carrier ( $\Delta \mathrm{Ex} 7$, case 2) (c). Translation of this mRNA product results in a protein that lacks 38 aminoacids encoded by exon 7 (p.Gly351_Pro388del) that could be visualized on immunoblots (lane $\triangle \mathrm{EX} 7$, case 2, d). For this patient, expression levels of the full length p62 protein are decreased by half. Protein extracts from transversal sections of spinal cord were prepared from patients carrying the c. $1165+1 \mathrm{G}>\mathrm{A}(\Delta \mathrm{Ex} 7$, case 2$)$, the c.259A $>\mathrm{G}$, p.Met87Val $(\mathrm{M} 87 \mathrm{~V}$, case 3$)$ and the c.304A>G, p.Lys102Glu (K102E, case 4) variants and three SALS with no genetic defect in SQSTM1. Protein levels of p62 and TDP-43 were compared in these patients. Samples were standardized using tubulin as internal control. Densitometric analyses of p62 (black) and TDP-43 (grey) protein levels. Data are means \pm standard error of the means (s.e.m.) of 5 values (from 5 independent western blot analyses) for each patient. Values for control SALS patients were pooled in a control group. For case 2 with c. $1165+1 \mathrm{G}>\mathrm{A}$ variant $(\Delta \mathrm{Ex} 7)$, p62 level is the sum of the two bands.

\section{Figure 3. Ubiquitinated inclusions in the spinal cord of patients with mutation in SQSTM1.}

Spinal cord sections were stained with anti-ubiquitin (a, d, g), anti-p62 (b, e, h) and anti-TDP-43 (c, f, i) antibodies. Skein like filamentous inclusions (d-f) and large round cytoplasmic inclusions (g-i) were detected with all three antibodies. Intracytoplasmic diffuse small granular aggregates were observed with ubiquitin (a) and TDP-43 (c) immunochemistry. This pattern was not found with p62 immunohistochemistry, in which bigger "seed-like", p62 positive aggregates were observed (b). Scale Bar: $10 \mu \mathrm{m}$. 
Figure 4. Cortical pathology in patients with SQSTM1 mutations.

In the midfrontal cortex of patients with p.Gly351_Pro388del ( $\triangle E x 7$, case 2) and with K102E (case 4) SQSTMI variants, immunochemistry showed TDP-43 (a-b) and p62 (c-d) positive intracytoplasmic inclusions. TDP-43 positive inclusions, either round or filamentous (black arrows), spread throughout the cortex with numerous thin neurites in case 2 (a, arrowheads) and only a few positive short neurites in case 4 (b). TDP-43 cortical pathology in case 2 and 4 resembles Type A and B pathology, respectively, according to Mackenzie classification [29]. In both patients, p62 immunohistochemistry showed a lower number of inclusions, generally round with no neurites (c-d). Scale Bar: $10 \mu \mathrm{m}$.

\section{Supplementary Figure 1. Colocalisation of p62 and TDP-43 in the inclusions.}

Double immunofluorescence analyses using p62 (in green) and TDP-43 (in red) antibodies were performed after deparaffinization using a procedure that was previously described [22]. Antibodies were diluted at 1:100 (p62) and 1:250 (TDP-43). Round (a) and seed-like (b) inclusions were positive for p62 and TDP-43 (arrows). Granular inclusions were positive for TDP-43 only (c, arrow heads). Presence of some lipofuscin is visible in the cell body of the motoneuron in (c). Scale bars: $10 \mu \mathrm{m}$. 
Table 1. Clinical features of studied populations

\begin{tabular}{|c|c|c|c|c|c|}
\hline & M:F ratio & $\begin{array}{l}\text { Age at onset } \\
\text { (years)* }\end{array}$ & $\begin{array}{l}\text { Site of disease } \\
\text { onset }\end{array}$ & $\begin{array}{l}\text { Disease } \\
\text { (months)* }\end{array}$ & duration \\
\hline $\begin{array}{l}\text { FALS } \\
\mathrm{n}=90\end{array}$ & $\begin{array}{l}1.9: 1 \\
(n=90)\end{array}$ & $\begin{array}{l}60+/-1.3 \\
(\mathrm{n}=86)\end{array}$ & $\begin{array}{l}43 \% \text { upper limbs } \\
34 \% \text { lower limbs } \\
23 \% \text { bulbar } \\
(\mathrm{n}=79)\end{array}$ & $\begin{array}{l}46+/-5 \\
(\mathrm{n}=64)^{* *}\end{array}$ & \\
\hline $\begin{array}{l}\text { SALS } \\
\mathrm{n}=74\end{array}$ & $\begin{array}{l}1.5: 1 \\
(\mathrm{n}=74)\end{array}$ & $\begin{array}{l}61+/-1 \\
(\mathrm{n}=72)\end{array}$ & $\begin{array}{l}27 \% \text { upper limbs } \\
42 \% \text { lower limbs } \\
31 \% \text { bulbar } \\
(\mathrm{n}=71)\end{array}$ & $\begin{array}{l}49+/-5 \\
(n=72)\end{array}$ & \\
\hline
\end{tabular}

*data are mean +/- standard error.

**disease duration data included 13 censored data for FALS.

$\mathrm{n}=$ number of patients for whom the information was available.

Table 2. Immunohistochemical methods

\begin{tabular}{|c|c|c|c|c|c|c|c|}
\hline Antigen & Species & Producer & Immunogen & Clone & Pretreatment & Dilution & $\begin{array}{l}\text { Incubation } \\
\text { time }\end{array}$ \\
\hline $\begin{array}{l}\text { CST3 } \\
\text { (cystatin-C) }\end{array}$ & $\begin{array}{l}\text { Polyclonal } \\
\text { (rabbit) }\end{array}$ & Sigma ${ }^{\circledR}$ & $\begin{array}{l}\text { Cystatin-C } \\
\text { precursor } \\
\text { recombinant } \\
\text { protein epitope } \\
\text { signature tag } \\
(\text { PrEST) }\end{array}$ & & $\begin{array}{l}\mathrm{CC} 2 \AA 36 \mathrm{~min} \\
\text { at } 95^{\circ} \mathrm{C}\end{array}$ & $1: 50$ & $\begin{array}{l}32 \min \\
+4^{\circ} \mathrm{C}\end{array}$ \\
\hline p62 lck ligand & $\begin{array}{l}\text { Monoclonal } \\
\text { (mouse) }\end{array}$ & $\begin{array}{l}\text { BD } \\
\text { Biosciences }{ }^{\circledR}\end{array}$ & $\begin{array}{l}\text { Human p62 lck } \\
\text { ligand aa. 257- } \\
437\end{array}$ & $257-437$ & $\begin{array}{l}\text { Citrate Buffer } \\
\mathrm{pH}=6 \\
\text { microwave }\end{array}$ & $1: 1000$ & $\begin{array}{l}\text { Overnight } \\
+4^{\circ} \mathrm{C}\end{array}$ \\
\hline $\begin{array}{l}\text { TARDBP } \\
\text { (TDP-43) }\end{array}$ & $\begin{array}{l}\text { Polyclonal } \\
\text { (rabbit) }\end{array}$ & $\begin{array}{ll}\text { Protein } & \text { Tech } \\
\text { Group } ® & \end{array}$ & $\begin{array}{l}\text { Human } \\
\text { recombinant } \\
\text { protein }\end{array}$ & & $\begin{array}{l}\mathrm{CC} 1 \AA 60 \mathrm{~min} \\
\text { at } 95^{\circ} \mathrm{C}\end{array}$ & $1: 1000$ & $\begin{array}{l}80 \mathrm{~min} \\
+20^{\circ} \mathrm{C}\end{array}$ \\
\hline Ubiquitin & $\begin{array}{l}\text { Polyclonal } \\
\text { (rabbit) }\end{array}$ & Dako® & $\begin{array}{l}\text { Ubiquitin } \\
\text { isolated from } \\
\text { cow erythrocytes }\end{array}$ & & $\begin{array}{l}\mathrm{CC} 1 \AA \text { at } 95^{\circ} \mathrm{C} \\
30 \mathrm{~min} \\
+\mathrm{FA} 10 \mathrm{~min}\end{array}$ & $1: 500$ & $\begin{array}{l}32 \mathrm{~min} \\
+4^{\circ} \mathrm{C}\end{array}$ \\
\hline
\end{tabular}


Table 3. Clinical characteristics of patients with SQSTM1 variants

\begin{tabular}{|c|c|c|c|c|c|c|c|c|}
\hline Patients & Type & Mutations & Gender & $\begin{array}{l}\text { Age at } \\
\text { onset (y) }\end{array}$ & $\begin{array}{l}\text { Site of disease } \\
\text { onset }\end{array}$ & $\begin{array}{ll}\begin{array}{l}\text { Disease } \\
\text { (months) }\end{array} & \text { duration } \\
\end{array}$ & FTD & $\begin{array}{l}\text { Paget's } \\
\text { disease } \\
\text { bone }\end{array}$ \\
\hline Case 1 & FALS & P392L & $\mathrm{M}$ & 54 & lower limbs & 133 & no & yes \\
\hline Case 2 & SALS & $\Delta \mathrm{EX} 7$ & $\mathrm{~F}$ & 75 & lower limbs & 42 & no & yes \\
\hline Case 3 & SALS & M87V & M & 68 & bulbar & 18 & NA & no \\
\hline Case 4 & SALS & K102E & $\mathrm{F}$ & 81 & bulbar & 10 & NA & no \\
\hline
\end{tabular}

NA: information was not available.

Supplementary Table 1. Semi-quantitative assessment for the presence of filamentous, round and granular inclusions stained by TDP-43 and p62.

\begin{tabular}{|c|c|c|c|c|c|c|}
\hline Patients & Type & $\begin{array}{l}\text { Genetic } \\
\text { Groups }\end{array}$ & IHC & Filamentous & Round & Granular \\
\hline Case 2 & SALS & $\begin{array}{l}\text { SQSTM1 } \\
(\Delta \mathrm{Ex} 7)\end{array}$ & $\begin{array}{l}\text { p62 } \\
\text { TDP-43 }\end{array}$ & $\begin{array}{l}1 \\
2\end{array}$ & $\begin{array}{l}1 \\
1\end{array}$ & $\begin{array}{l}0 \\
1\end{array}$ \\
\hline Case 3 & SALS & $\begin{array}{l}\text { SQSTM1 } \\
\text { (M87V) }\end{array}$ & $\begin{array}{l}\text { p62 } \\
\text { TDP-43 }\end{array}$ & $\begin{array}{l}1 \\
2\end{array}$ & $\begin{array}{l}1 \\
2\end{array}$ & $\begin{array}{l}0 \\
3\end{array}$ \\
\hline Case 4 & SALS & $\begin{array}{l}\text { SQSTM1 } \\
\text { (K102E) }\end{array}$ & $\begin{array}{l}\text { p62 } \\
\text { TDP-43 }\end{array}$ & $\begin{array}{l}1 \\
3 \\
\end{array}$ & $\begin{array}{l}2 \\
2 \\
\end{array}$ & $\begin{array}{l}0 \\
3 \\
\end{array}$ \\
\hline Case 5 & FALS & C9ORF72 & $\begin{array}{l}\text { p62 } \\
\text { TDP-43 }\end{array}$ & $\begin{array}{l}0 \\
0\end{array}$ & $\begin{array}{l}0 \\
1\end{array}$ & $\begin{array}{l}0 \\
0\end{array}$ \\
\hline Case 6 & SALS & C9ORF72 & $\begin{array}{l}\text { p62 } \\
\text { TDP-43 }\end{array}$ & $\begin{array}{l}2 \\
1 \\
\end{array}$ & $\begin{array}{l}2 \\
1 \\
\end{array}$ & $\begin{array}{l}0 \\
1 \\
\end{array}$ \\
\hline Case 7 & FALS & C9ORF72 & $\begin{array}{l}\text { p62 } \\
\text { TDP-43 }\end{array}$ & $\begin{array}{l}0 \\
3\end{array}$ & $\begin{array}{l}0 \\
1\end{array}$ & $\begin{array}{l}1 \\
2\end{array}$ \\
\hline Case 8 & SALS & C9ORF72 & $\begin{array}{l}\text { p62 } \\
\text { TDP-43 }\end{array}$ & $\begin{array}{l}1 \\
2\end{array}$ & $\begin{array}{l}1 \\
1\end{array}$ & $\begin{array}{l}0 \\
0\end{array}$ \\
\hline Case 9 & FALS & C9ORF72 & $\begin{array}{l}\text { p62 } \\
\text { TDP-43 }\end{array}$ & $\begin{array}{l}3 \\
3\end{array}$ & $\begin{array}{l}1 \\
1\end{array}$ & $\begin{array}{l}2 \\
2\end{array}$ \\
\hline Case 10 & SALS & C9ORF72 & $\begin{array}{l}\text { p62 } \\
\text { TDP-43 }\end{array}$ & $\begin{array}{l}2 \\
1\end{array}$ & $\begin{array}{l}0 \\
1\end{array}$ & $\begin{array}{l}1 \\
1\end{array}$ \\
\hline Case 11 & FALS & C9ORF72 & $\begin{array}{l}\text { p62 } \\
\text { TDP-43 }\end{array}$ & $\begin{array}{l}2 \\
2 \\
\end{array}$ & $\begin{array}{l}0 \\
0 \\
\end{array}$ & $\begin{array}{l}0 \\
1 \\
\end{array}$ \\
\hline Case 12 & FALS & C9ORF72 & $\begin{array}{l}\text { p62 } \\
\text { TDP-43 }\end{array}$ & $\begin{array}{l}2 \\
3 \\
\end{array}$ & $\begin{array}{l}1 \\
0 \\
\end{array}$ & $\begin{array}{l}1 \\
1 \\
\end{array}$ \\
\hline Case 13 & FALS & SOD1 & $\begin{array}{l}\text { p62 } \\
\text { TDP-43 }\end{array}$ & $\begin{array}{l}0 \\
0 \\
\end{array}$ & $\begin{array}{l}0 \\
0\end{array}$ & $\begin{array}{l}0 \\
0\end{array}$ \\
\hline Case 14 & FALS & SOD1 & $\begin{array}{l}\text { p62 } \\
\text { TDP-43 }\end{array}$ & $\begin{array}{l}0 \\
0 \\
\end{array}$ & $\begin{array}{l}1 \\
0\end{array}$ & $\begin{array}{l}3 \\
0 \\
\end{array}$ \\
\hline Case 15 & SALS & SOD1 & $\begin{array}{l}\text { p62 } \\
\text { TDP-43 }\end{array}$ & $\begin{array}{l}0 \\
0 \\
\end{array}$ & $\begin{array}{l}1 \\
1 \\
\end{array}$ & $\begin{array}{l}1 \\
1 \\
\end{array}$ \\
\hline Case 16 & SALS & SOD1 & $\begin{array}{l}\text { p62 } \\
\text { TDP-43 }\end{array}$ & $\begin{array}{l}0 \\
0\end{array}$ & $\begin{array}{l}0 \\
0 \\
\end{array}$ & $\begin{array}{l}0 \\
0 \\
\end{array}$ \\
\hline Case 17 & FALS & TARDBP & $\begin{array}{l}\text { p62 } \\
\text { TDP-43 }\end{array}$ & $\begin{array}{l}1 \\
3 \\
\end{array}$ & $\begin{array}{l}0 \\
1 \\
\end{array}$ & $\begin{array}{l}0 \\
1 \\
\end{array}$ \\
\hline Case 18 & SALS & TARDBP & $\begin{array}{l}\text { p62 } \\
\text { TDP-43 }\end{array}$ & $\begin{array}{l}0 \\
1 \\
\end{array}$ & $\begin{array}{l}0 \\
0\end{array}$ & $\begin{array}{l}0 \\
0\end{array}$ \\
\hline Case 19 & SALS & - & $\begin{array}{l}\text { p62 } \\
\text { TDP-43 }\end{array}$ & $\begin{array}{l}0 \\
1\end{array}$ & $\begin{array}{l}0 \\
2\end{array}$ & $\begin{array}{l}1 \\
1\end{array}$ \\
\hline Case 20 & SALS & - & $\begin{array}{l}\text { p62 } \\
\text { TDP-43 }\end{array}$ & $\begin{array}{l}0 \\
1 \\
\end{array}$ & $\begin{array}{l}0 \\
2 \\
\end{array}$ & $\begin{array}{l}0 \\
0 \\
\end{array}$ \\
\hline Case 21 & SALS & - & $\begin{array}{l}\text { p62 } \\
\text { TDP-43 }\end{array}$ & $\begin{array}{l}1 \\
2 \\
\end{array}$ & $\begin{array}{l}1 \\
2 \\
\end{array}$ & $\begin{array}{l}0 \\
0 \\
\end{array}$ \\
\hline Case 22 & SALS & - & $\begin{array}{l}\text { p62 } \\
\text { TDP-43 }\end{array}$ & $\begin{array}{l}1 \\
0\end{array}$ & $\begin{array}{l}1 \\
2 \\
\end{array}$ & $\begin{array}{l}0 \\
0 \\
\end{array}$ \\
\hline Case 23 & SALS & - & $\begin{array}{l}\text { p62 } \\
\text { TDP-43 }\end{array}$ & $\begin{array}{l}1 \\
2\end{array}$ & $\begin{array}{l}0 \\
1\end{array}$ & $\begin{array}{l}0 \\
0\end{array}$ \\
\hline
\end{tabular}




\begin{tabular}{|c|c|c|c|c|c|c|}
\hline Case 24 & SALS & - & $\begin{array}{l}\text { p62 } \\
\text { TDP-43 }\end{array}$ & $\begin{array}{l}0 \\
0\end{array}$ & $\begin{array}{l}0 \\
0\end{array}$ & $\begin{array}{l}0 \\
1\end{array}$ \\
\hline Case 25 & SALS & - & $\begin{array}{l}\text { p62 } \\
\text { TDP-43 }\end{array}$ & $\begin{array}{l}0 \\
3\end{array}$ & $\begin{array}{l}1 \\
2\end{array}$ & $\begin{array}{l}0 \\
2\end{array}$ \\
\hline Case 26 & SALS & - & $\begin{array}{l}\text { p62 } \\
\text { TDP-43 }\end{array}$ & $\begin{array}{l}0 \\
1\end{array}$ & $\begin{array}{l}0 \\
0\end{array}$ & $\begin{array}{l}0 \\
0\end{array}$ \\
\hline Case 27 & SALS & - & $\begin{array}{l}\text { p62 } \\
\text { TDP-43 }\end{array}$ & $\begin{array}{l}0 \\
1\end{array}$ & $\begin{array}{l}0 \\
0\end{array}$ & $\begin{array}{l}1 \\
1\end{array}$ \\
\hline Case 28 & SALS & - & $\begin{array}{l}\text { p62 } \\
\text { TDP-43 }\end{array}$ & $\begin{array}{l}2 \\
3\end{array}$ & $\begin{array}{l}0 \\
0\end{array}$ & $\begin{array}{l}1 \\
1\end{array}$ \\
\hline Case 29 & SALS & - & $\begin{array}{l}\text { p62 } \\
\text { TDP-43 }\end{array}$ & $\begin{array}{l}0 \\
0\end{array}$ & $\begin{array}{l}1 \\
1\end{array}$ & $\begin{array}{l}0 \\
2\end{array}$ \\
\hline Case 30 & SALS & - & $\begin{array}{l}\text { p62 } \\
\text { TDP-43 }\end{array}$ & $\begin{array}{l}2 \\
2\end{array}$ & $\begin{array}{l}1 \\
0\end{array}$ & $\begin{array}{l}0 \\
1\end{array}$ \\
\hline Case 31 & SALS & - & $\begin{array}{l}\text { p62 } \\
\text { TDP-43 }\end{array}$ & $\begin{array}{l}1 \\
1 \\
\end{array}$ & $\begin{array}{l}0 \\
0\end{array}$ & $\begin{array}{l}2 \\
0 \\
\end{array}$ \\
\hline Case 32 & SALS & - & $\begin{array}{l}\text { p62 } \\
\text { TDP-43 }\end{array}$ & $\begin{array}{l}0 \\
0\end{array}$ & $\begin{array}{l}1 \\
1\end{array}$ & $\begin{array}{l}0 \\
2\end{array}$ \\
\hline Case 33 & SALS & - & $\begin{array}{l}\text { p62 } \\
\text { TDP-43 }\end{array}$ & $\begin{array}{l}1 \\
1\end{array}$ & $\begin{array}{l}0 \\
1\end{array}$ & $\begin{array}{l}1 \\
1\end{array}$ \\
\hline Case 34 & SALS & - & $\begin{array}{l}\text { p62 } \\
\text { TDP-43 }\end{array}$ & $\begin{array}{l}0 \\
0\end{array}$ & $\begin{array}{l}0 \\
1\end{array}$ & $\begin{array}{l}0 \\
2\end{array}$ \\
\hline Case 35 & SALS & - & $\begin{array}{l}\text { p62 } \\
\text { TDP-43 }\end{array}$ & $\begin{array}{l}0 \\
0\end{array}$ & $\begin{array}{l}0 \\
2\end{array}$ & $\begin{array}{l}0 \\
1\end{array}$ \\
\hline Case 36 & SALS & - & $\begin{array}{l}\text { p62 } \\
\text { TDP-43 }\end{array}$ & $\begin{array}{l}0 \\
2\end{array}$ & $\begin{array}{l}0 \\
0\end{array}$ & $\begin{array}{l}0 \\
0\end{array}$ \\
\hline Case 37 & SALS & - & $\begin{array}{l}\text { p62 } \\
\text { TDP-43 }\end{array}$ & $\begin{array}{l}1 \\
1\end{array}$ & $\begin{array}{l}1 \\
1\end{array}$ & $\begin{array}{l}0 \\
0\end{array}$ \\
\hline Case 38 & SALS & - & $\begin{array}{l}\text { p62 } \\
\text { TDP-43 }\end{array}$ & $\begin{array}{l}1 \\
2\end{array}$ & $\begin{array}{l}1 \\
1\end{array}$ & $\begin{array}{l}0 \\
3\end{array}$ \\
\hline Case 39 & SALS & - & $\begin{array}{l}\text { p62 } \\
\text { TDP-43 }\end{array}$ & $\begin{array}{l}0 \\
1\end{array}$ & $\begin{array}{l}0 \\
1\end{array}$ & $\begin{array}{l}0 \\
3\end{array}$ \\
\hline Case 40 & SALS & - & $\begin{array}{l}\text { p62 } \\
\text { TDP-43 }\end{array}$ & $\begin{array}{l}0 \\
0\end{array}$ & $\begin{array}{l}0 \\
1\end{array}$ & $\begin{array}{l}0 \\
0\end{array}$ \\
\hline Case 41 & SALS & - & $\begin{array}{l}\text { p62 } \\
\text { TDP-43 }\end{array}$ & $\begin{array}{l}0 \\
0\end{array}$ & $\begin{array}{l}0 \\
0\end{array}$ & $\begin{array}{l}0 \\
0\end{array}$ \\
\hline Case 42 & SALS & - & $\begin{array}{l}\text { p62 } \\
\text { TDP-43 }\end{array}$ & $\begin{array}{l}1 \\
3\end{array}$ & $\begin{array}{l}0 \\
0\end{array}$ & $\begin{array}{l}1 \\
2\end{array}$ \\
\hline Case 43 & SALS & - & $\begin{array}{l}\text { p62 } \\
\text { TDP-43 }\end{array}$ & $\begin{array}{l}1 \\
3\end{array}$ & $\begin{array}{l}0 \\
1\end{array}$ & $\begin{array}{l}1 \\
3\end{array}$ \\
\hline Case 44 & SALS & - & $\begin{array}{l}\text { p62 } \\
\text { TDP-43 }\end{array}$ & $\begin{array}{l}2 \\
2\end{array}$ & $\begin{array}{l}1 \\
2\end{array}$ & $\begin{array}{l}1 \\
3\end{array}$ \\
\hline Case 45 & SALS & - & $\begin{array}{l}\text { p62 } \\
\text { TDP-43 }\end{array}$ & $\begin{array}{l}0 \\
2\end{array}$ & $\begin{array}{l}0 \\
1\end{array}$ & $\begin{array}{l}1 \\
1\end{array}$ \\
\hline Case 46 & SALS & - & $\begin{array}{l}\text { p62 } \\
\text { TDP-43 }\end{array}$ & $\begin{array}{l}1 \\
2\end{array}$ & $\begin{array}{l}1 \\
2\end{array}$ & $\begin{array}{l}0 \\
2\end{array}$ \\
\hline
\end{tabular}

0 , none; 1 , rare; 2 , moderate; 3 , severe

-, no mutation in the screened genes.

\section{References}

1. Al-Sarraj S, King A, Troakes C, Smith B, Maekawa S, Bodi I, Rogelj B, Al-Chalabi A, Hortobagyi T, Shaw CE (2011) p62 positive, TDP-43 negative, neuronal cytoplasmic and intranuclear inclusions in the cerebellum and hippocampus define the pathology of C9orf72-linked FTLD and MND/ALS. Acta Neuropathol 122:691-702

2. Albagha OM, Visconti MR, Alonso N, Langston AL, Cundy T, Dargie R, Dunlop MG, Fraser WD, Hooper MJ, Isaia G, Nicholson GC, del Pino Montes J, Gonzalez-Sarmiento R, di Stefano M, Tenesa A, Walsh JP, Ralston SH (2010) Genome-wide association study identifies variants at CSF1, OPTN and TNFRSF11A as genetic risk factors for Paget's disease of bone. Nat Genet 42:520-524

3. Brady OA, Meng P, Zheng Y, Mao Y, Hu F (2011) Regulation of TDP-43 aggregation by phosphorylation and p62/SQSTM1. J Neurochem 116:248-259

4. Brettschneider J, Libon DJ, Toledo JB, Xie SX, McCluskey L, Elman L, Geser F, Lee VM, Grossman M, Trojanowski JQ (2012) Microglial activation and TDP-43 pathology correlate with executive dysfunction in amyotrophic lateral sclerosis. Acta Neuropathol 123:395-407 
5. Brettschneider J, Van Deerlin VM, Robinson JL, Kwong L, Lee EB, Ali YO, Safren N, Monteiro MJ, Toledo JB, Elman L, McCluskey L, Irwin DJ, Grossman M, Molina-Porcel L, Lee VM, Trojanowski JQ (2012) Pattern of ubiquilin pathology in ALS and FTLD indicates presence of C9ORF72 hexanucleotide expansion. Acta Neuropathol 123:825-839

6. Brooks BR, Miller RG, Swash M, Munsat TL (2000) El Escorial revisited: revised criteria for the diagnosis of amyotrophic lateral sclerosis. Amyotroph Lateral Scler Other Motor Neuron Disord 1:293-299

7. Cavey JR, Ralston SH, Sheppard PW, Ciani B, Gallagher TR, Long JE, Searle MS, Layfield R (2006) Loss of ubiquitin binding is a unifying mechanism by which mutations of SQSTM1 cause Paget's disease of bone. Calcif Tissue Int 78:271-277

8. Collet C, Michou L, Audran M, Chasseigneaux S, Hilliquin P, Bardin T, Lemaire I, Cornelis F, Launay JM, Orcel P, Laplanche JL (2007) Paget's disease of bone in the French population: novel SQSTM1 mutations, functional analysis, and genotype-phenotype correlations. J Bone Miner Res 22:310-317

9. Cooper C, Schafheutle K, Dennison E, Kellingray S, Guyer P, Barker D (1999) The epidemiology of Paget's disease in Britain: is the prevalence decreasing? J Bone Miner Res 14:192-197

10. Dai RM, Li CC (2001) Valosin-containing protein is a multi-ubiquitin chain-targeting factor required in ubiquitin-proteasome degradation. Nat Cell Biol 3:740-744

11. Daroszewska A, van 't Hof RJ, Rojas JA, Layfield R, Landao-Basonga E, Rose L, Rose K, Ralston SH (2011) A point mutation in the ubiquitin-associated domain of SQSMT1 is sufficient to cause a Paget's diseaselike disorder in mice. Hum Mol Genet 20:2734-2744

12. Dejesus-Hernandez M, Mackenzie IR, Boeve BF, Boxer AL, Baker M, Rutherford NJ, Nicholson AM, Finch NA, Flynn H, Adamson J, Kouri N, Wojtas A, Sengdy P, Hsiung GY, Karydas A, Seeley WW, Josephs KA, Coppola G, Geschwind DH, Wszolek ZK, Feldman H, Knopman DS, Petersen RC, Miller BL, Dickson DW, Boylan KB, Graff-Radford NR, Rademakers R (2011) Expanded GGGGCC Hexanucleotide Repeat in Noncoding Region of C9ORF72 Causes Chromosome 9p-Linked FTD and ALS. Neuron 72:245-256

13. Falchetti A, Di Stefano M, Marini F, Ortolani S, Ulivieri MF, Bergui S, Masi L, Cepollaro C, Benucci M, Di Munno O, Rossini M, Adami S, Del Puente A, Isaia G, Torricelli F, Brandi ML (2009) Genetic epidemiology of Paget's disease of bone in italy: sequestosome1/p62 gene mutational test and haplotype analysis at $5 q 35$ in a large representative series of sporadic and familial Italian cases of Paget's disease of bone. Calcif Tissue Int 84:20-37

14. Fecto F, Yan J, Vemula SP, Liu E, Yang Y, Chen W, Zheng JG, Shi Y, Siddique N, Arrat H, Donkervoort S, Ajroud-Driss S, Sufit RL, Heller SL, Deng HX, Siddique T (2011) SQSTM1 mutations in familial and sporadic amyotrophic lateral sclerosis. Arch Neurol 68:1440-1446

15. Geetha T, Vishwaprakash N, Sycheva M, Babu JR (2012) Sequestosome 1/p62: across diseases. Biomarkers 17:99-103

16. Geser F, Robinson JL, Malunda JA, Xie SX, Clark CM, Kwong LK, Moberg PJ, Moore EM, Van Deerlin VM, Lee VM, Arnold SE, Trojanowski JQ (2010) Pathological 43-kDa transactivation response DNAbinding protein in older adults with and without severe mental illness. Arch Neurol 67:1238-1250

17. Geser F, Stein B, Partain M, Elman LB, McCluskey LF, Xie SX, Van Deerlin VM, Kwong LK, Lee VM, Trojanowski JQ (2011) Motor neuron disease clinically limited to the lower motor neuron is a diffuse TDP43 proteinopathy. Acta Neuropathol 121:509-517

18. Gleason CE, Ordureau A, Gourlay R, Arthur JS, Cohen P (2011) Polyubiquitin binding to optineurin is required for optimal activation of TANK-binding kinase 1 and production of interferon beta. $\mathrm{J}$ Biol Chem 286:35663-35674

19. Goode A, Layfield R (2010) Recent advances in understanding the molecular basis of Paget disease of bone. J Clin Pathol 63:199-203

20. Hamdy RC (1995) Clinical features and pharmacologic treatment of Paget's disease. Endocrinol Metab Clin North Am 24:421-436

21. Hart MP, Brettschneider J, Lee VM, Trojanowski JQ, Gitler AD (2012) Distinct TDP-43 pathology in ALS patients with ataxin 2 intermediate-length polyQ expansions. Acta Neuropathol 124:221-230

22. Hernandez Lain A, Millecamps S, Dubourg O, Salachas F, Bruneteau G, Lacomblez L, LeGuern E, Seilhean D, Duyckaerts C, Meininger V, Mallet J, Pradat PF (2011) Abnormal TDP-43 and FUS proteins in muscles of sporadic IBM: similarities in a TARDBP-linked ALS patient. J Neurol Neurosurg Psychiatry 82:1414-1416

23. Hirano M, Nakamura Y, Saigoh K, Sakamoto H, Ueno S, Isono C, Miyamoto K, Akamatsu M, Mitsui Y, Kusunoki S (2013) Mutations in the gene encoding p62 in Japanese patients with amyotrophic lateral sclerosis. Neurology doi: 10.1212/WNL.0b013e31827f0fe5 
24. Hocking LJ, Lucas GJ, Daroszewska A, Mangion J, Olavesen M, Cundy T, Nicholson GC, Ward L, Bennett ST, Wuyts W, Van Hul W, Ralston SH (2002) Domain-specific mutations in sequestosome 1 (SQSTM1) cause familial and sporadic Paget's disease. Hum Mol Genet 11:2735-2739

25. Johnson JO, Mandrioli J, Benatar M, Abramzon Y, Van Deerlin VM, Trojanowski JQ, Gibbs JR, Brunetti M, Gronka S, Wuu J, Ding J, McCluskey L, Martinez-Lage M, Falcone D, Hernandez DG, Arepalli S, Chong S, Schymick JC, Rothstein J, Landi F, Wang YD, Calvo A, Mora G, Sabatelli M, Monsurro MR, Battistini S, Salvi F, Spataro R, Sola P, Borghero G, Galassi G, Scholz SW, Taylor JP, Restagno G, Chio A, Traynor BJ (2010) Exome sequencing reveals VCP mutations as a cause of familial ALS. Neuron 68:857-864

26. Kuusisto E, Salminen A, Alafuzoff I (2001) Ubiquitin-binding protein p62 is present in neuronal and glial inclusions in human tauopathies and synucleinopathies. Neuroreport 12:2085-2090

27. Laurin N, Brown JP, Morissette J, Raymond V (2002) Recurrent mutation of the gene encoding sequestosome 1 (SQSTM1/p62) in Paget disease of bone. Am J Hum Genet 70:1582-1588

28. Mackenzie IR, Bigio EH, Ince PG, Geser F, Neumann M, Cairns NJ, Kwong LK, Forman MS, Ravits J, Stewart H, Eisen A, McClusky L, Kretzschmar HA, Monoranu CM, Highley JR, Kirby J, Siddique T, Shaw PJ, Lee VM, Trojanowski JQ (2007) Pathological TDP-43 distinguishes sporadic amyotrophic lateral sclerosis from amyotrophic lateral sclerosis with SOD1 mutations. Ann Neurol 61:427-434

29. Mackenzie IR, Neumann M, Baborie A, Sampathu DM, Du Plessis D, Jaros E, Perry RH, Trojanowski JQ, Mann DM, Lee VM (2011) A harmonized classification system for FTLD-TDP pathology. Acta Neuropathol 122:111-113

30. Maruyama H, Morino H, Ito H, Izumi Y, Kato H, Watanabe Y, Kinoshita Y, Kamada M, Nodera H, Suzuki H, Komure O, Matsuura S, Kobatake K, Morimoto N, Abe K, Suzuki N, Aoki M, Kawata A, Hirai T, Kato T, Ogasawara K, Hirano A, Takumi T, Kusaka H, Hagiwara K, Kaji R, Kawakami H (2010) Mutations of optineurin in amyotrophic lateral sclerosis. Nature 465:223-226

31. Michou L, Collet C, Laplanche JL, Orcel P, Cornelis F (2006) Genetics of Paget's disease of bone. Joint Bone Spine 73:243-248

32. Michou L, Collet C, Morissette J, Audran M, Thomas T, Gagnon E, Launay JM, Laplanche JL, Brown JP, Orcel P (2012) Epidemiogenetic study of French families with Paget's disease of bone. Joint Bone Spine 79:393-398

33. Millecamps S, Boillee S, Chabrol E, Camu W, Cazeneuve C, Salachas F, Pradat PF, Danel-Brunaud V, Vandenberghe N, Corcia P, Le Forestier N, Lacomblez L, Bruneteau G, Seilhean D, Brice A, Feingold J, Meininger V, LeGuern E (2011) Screening of OPTN in French familial amyotrophic lateral sclerosis. Neurobiol Aging 32:557 e511-553

34. Millecamps S, Boillee S, Le Ber I, Seilhean D, Teyssou E, Giraudeau M, Moigneu C, Vandenberghe N, Danel-Brunaud V, Corcia P, Pradat PF, Le Forestier N, Lacomblez L, Bruneteau G, Camu W, Brice A, Cazeneuve C, Leguern E, Meininger V, Salachas F (2012) Phenotype difference between ALS patients with expanded repeats in C9ORF72 and patients with mutations in other ALS-related genes. J Med Genet 49:258-263

35. Millecamps S, Corcia P, Cazeneuve C, Boillee S, Seilhean D, Danel-Brunaud V, Vandenberghe N, Pradat PF, Le Forestier N, Lacomblez L, Bruneteau G, Camu W, Brice A, Meininger V, LeGuern E, Salachas F (2012) Mutations in UBQLN2 are rare in French amyotrophic lateral sclerosis. Neurobiol Aging 33:839 e831833

36. Millecamps S, Da Barroca S, Cazeneuve C, Salachas F, Pradat PF, Danel-Brunaud V, Vandenberghe N, Lacomblez L, Le Forestier N, Bruneteau G, Camu W, Brice A, Meininger V, LeGuern E (2010) Questioning on the role of D amino acid oxidase in familial amyotrophic lateral sclerosis. Proc Natl Acad Sci U S A 107:E107; author reply E108

37. Millecamps S, Salachas F, Cazeneuve C, Gordon P, Bricka B, Camuzat A, Guillot-Noel L, Russaouen O, Bruneteau G, Pradat PF, Le Forestier N, Vandenberghe N, Danel-Brunaud V, Guy N, Thauvin-Robinet C, Lacomblez L, Couratier P, Hannequin D, Seilhean D, Le Ber I, Corcia P, Camu W, Brice A, Rouleau G, Leguern E, Meininger V (2010) SOD1, ANG, VAPB, TARDBP, and FUS mutations in familial amyotrophic lateral sclerosis: genotype-phenotype correlations. J Med Genet 47:554-560

38. Mizuno Y, Amari M, Takatama M, Aizawa H, Mihara B, Okamoto K (2006) Immunoreactivities of p62, an ubiqutin-binding protein, in the spinal anterior horn cells of patients with amyotrophic lateral sclerosis. J Neurol Sci 249:13-18

39. Neumann M, Sampathu DM, Kwong LK, Truax AC, Micsenyi MC, Chou TT, Bruce J, Schuck T, Grossman M, Clark CM, McCluskey LF, Miller BL, Masliah E, Mackenzie IR, Feldman H, Feiden W, Kretzschmar HA, Trojanowski JQ, Lee VM (2006) Ubiquitinated TDP-43 in frontotemporal lobar degeneration and amyotrophic lateral sclerosis. Science 314:130-133 
40. Okamoto K, Hirai S, Amari M, Watanabe M, Sakurai A (1993) Bunina bodies in amyotrophic lateral sclerosis immunostained with rabbit anti-cystatin C serum. Neurosci Lett 162:125-128

41. Pikkarainen M, Hartikainen P, Alafuzoff I (2008) Neuropathologic features of frontotemporal lobar degeneration with ubiquitin-positive inclusions visualized with ubiquitin-binding protein p62 immunohistochemistry. J Neuropathol Exp Neurol 67:280-298

42. Ramesh Babu J, Lamar Seibenhener M, Peng J, Strom AL, Kemppainen R, Cox N, Zhu H, Wooten MC, Diaz-Meco MT, Moscat J, Wooten MW (2008) Genetic inactivation of p62 leads to accumulation of hyperphosphorylated tau and neurodegeneration. J Neurochem 106:107-120

43. Renton AE, Majounie E, Waite A, Simon-Sanchez J, Rollinson S, Gibbs JR, Schymick JC, Laaksovirta H, van Swieten JC, Myllykangas L, Kalimo H, Paetau A, Abramzon Y, Remes AM, Kaganovich A, Scholz SW, Duckworth J, Ding J, Harmer DW, Hernandez DG, Johnson JO, Mok K, Ryten M, Trabzuni D, Guerreiro RJ, Orrell RW, Neal J, Murray A, Pearson J, Jansen IE, Sondervan D, Seelaar H, Blake D, Young K, Halliwell N, Callister JB, Toulson G, Richardson A, Gerhard A, Snowden J, Mann D, Neary D, Nalls MA, Peuralinna T, Jansson L, Isoviita VM, Kaivorinne AL, Holtta-Vuori M, Ikonen E, Sulkava R, Benatar M, Wuu J, Chio A, Restagno G, Borghero G, Sabatelli M, Heckerman D, Rogaeva E, Zinman L, Rothstein JD, Sendtner M, Drepper C, Eichler EE, Alkan C, Abdullaev Z, Pack SD, Dutra A, Pak E, Hardy J, Singleton A, Williams NM, Heutink P, Pickering-Brown S, Morris HR, Tienari PJ, Traynor BJ (2011) A Hexanucleotide Repeat Expansion in C9ORF72 Is the Cause of Chromosome 9p21-Linked ALS-FTD. Neuron 72:257-268

44. Rubino E, Rainero I, Chio A, Rogaeva E, Galimberti D, Fenoglio P, Grinberg Y, Isaia G, Calvo A, Gentile S, Bruni AC, St George-Hyslop PH, Scarpini E, Gallone S, Pinessi L (2012) SQSTM1 mutations in frontotemporal lobar degeneration and amyotrophic lateral sclerosis. Neurology 79:1556-1562

45. Tanji K, Zhang HX, Mori F, Kakita A, Takahashi H, Wakabayashi K (2012) p62/sequestosome 1 binds to TDP-43 in brains with frontotemporal lobar degeneration with TDP-43 inclusions. J Neurosci Res 90:20342042

46. Vadlamudi RK, Joung I, Strominger JL, Shin J (1996) p62, a phosphotyrosine-independent ligand of the SH2 domain of p56lck, belongs to a new class of ubiquitin-binding proteins. J Biol Chem 271:20235-20237

47. Watts GD, Wymer J, Kovach MJ, Mehta SG, Mumm S, Darvish D, Pestronk A, Whyte MP, Kimonis VE (2004) Inclusion body myopathy associated with Paget disease of bone and frontotemporal dementia is caused by mutant valosin-containing protein. Nat Genet 36:377-381 
a
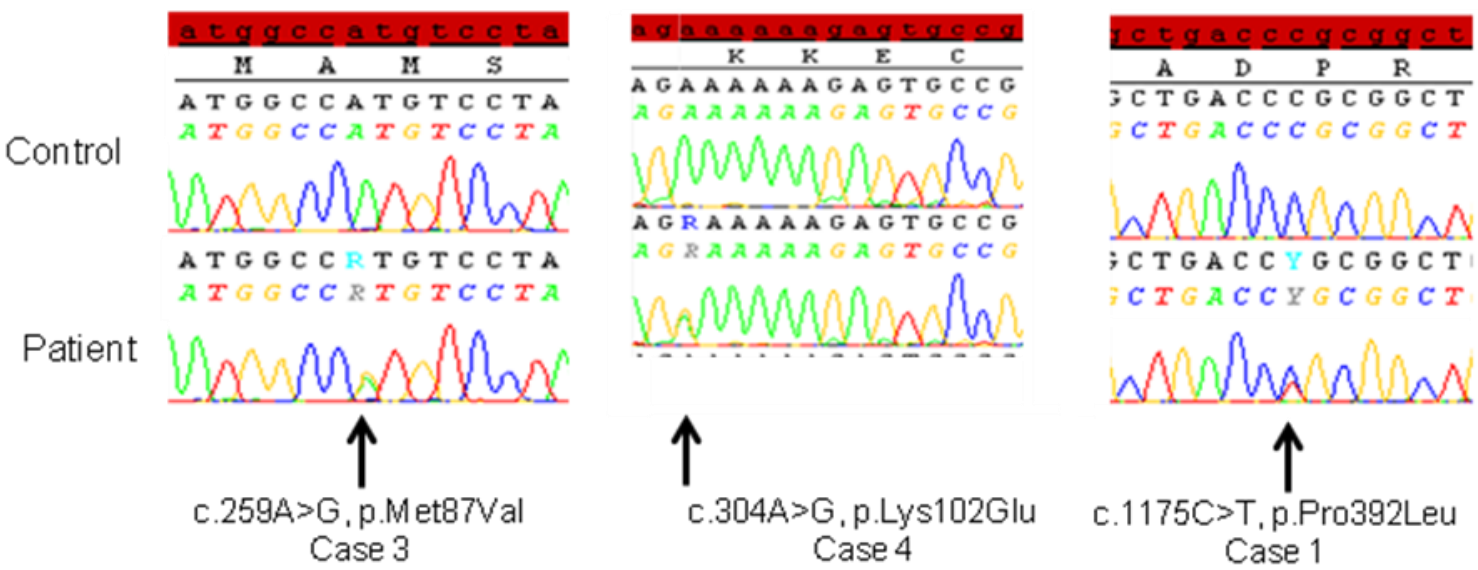

$C T G A C C C G C G G C T$

$A G R A A A A A G A G T G C C$
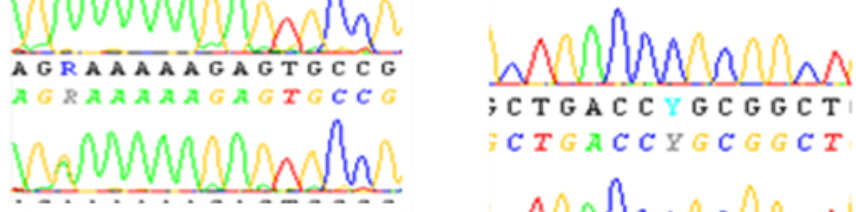

; C T G A C C Y C G G C T

$C T G A C C Y G C G G C T$
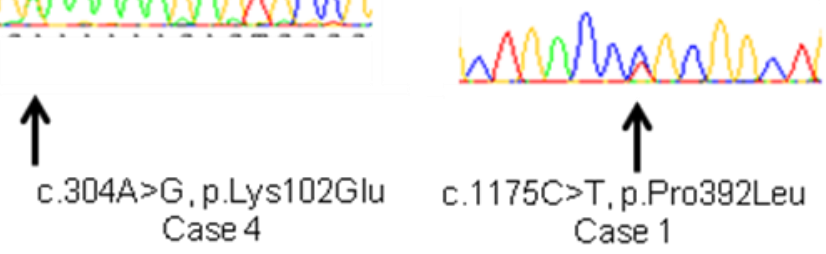

b

Homo sapiens

Pan troglodytes

Bos taurus

Rattus norvegicus

Mus musculus

Gallus gallus

Xenopus laevis
$81 \downarrow$

EEL TMAMSYV KDDIFRIYIK EKKECRRDHR EEL TMAMSYV KDDIFRIYIK EKKECRRDHR EEL TMAMSYV KDDIFRIYIK EKKECRRDQR EEL TMAMSYV KDDIFRIYIK EKKECRREHR EEL TMAMSYV KDDIFRIYIK EKKECRREHR EELDLAIPYV QDGUFRUYIK EKKECRREHR EELHMGLSLL HEDVFRIYIK EKKECKRDHR $\checkmark \quad 400$ ALYPHLPPEA DPRLIESLSQ ALYPHLPPEA DPRLIESLSQ ALYPHLPPEA DPRLIESLSQ ALYPHLPPEA DPRLIESLSQ ALYPHLPPEA DPRLIESLSQ ALYPHLPPEA DPRLIESLSQ ALYPHLPPEA DPRLIETLSQ

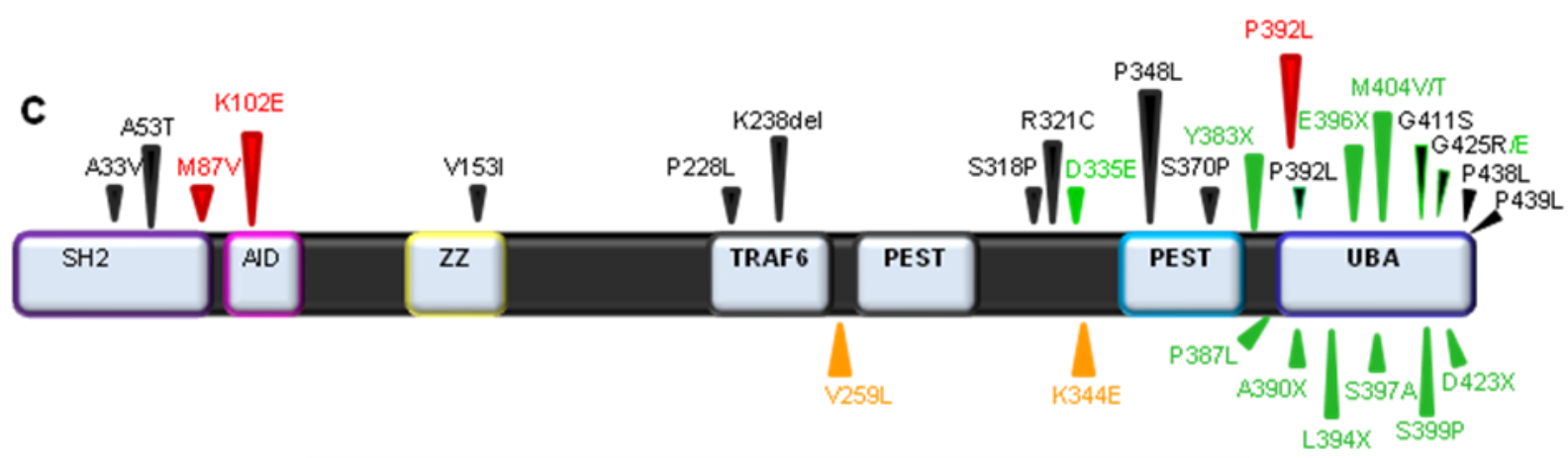

d

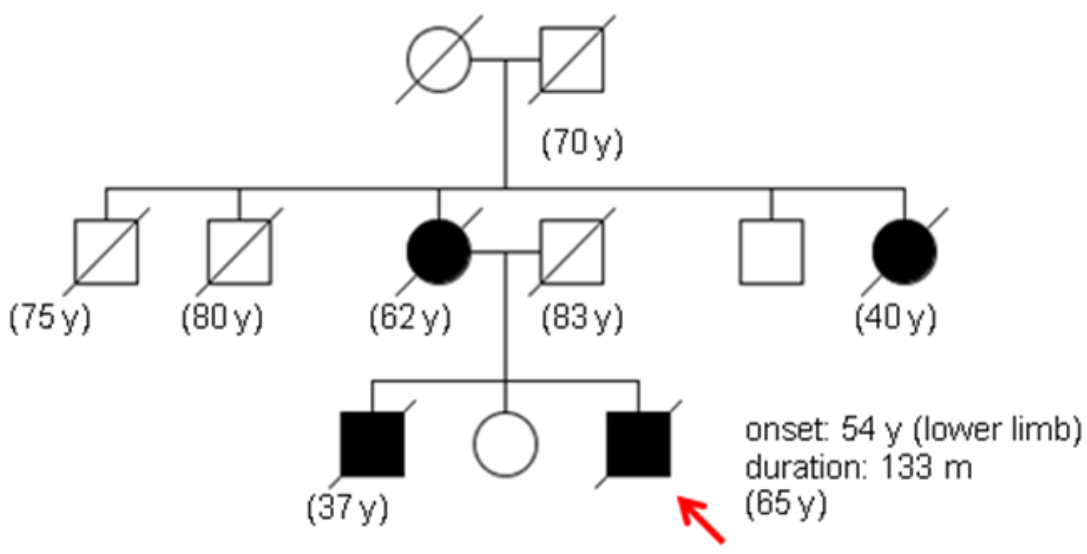

Fig. 1 
a

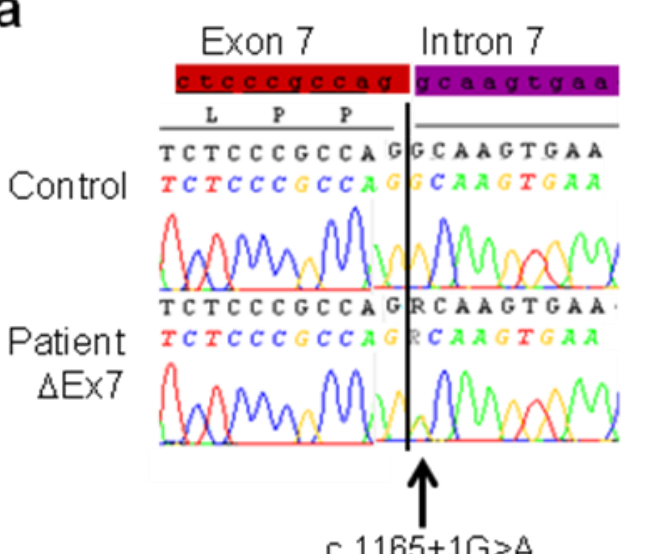

c. $1165+1 G>A$

b

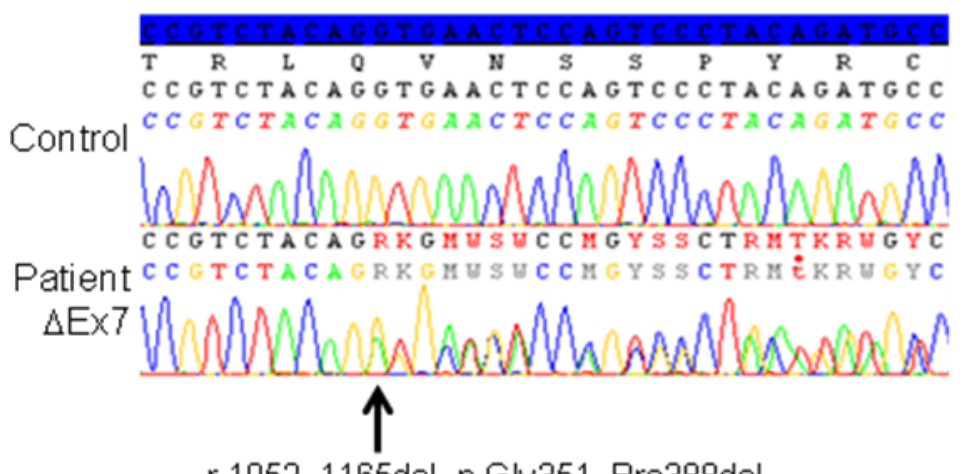

r.1052_1165del, p.Gly351_Pro388del

d

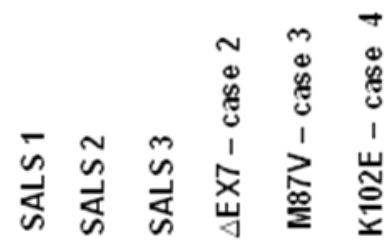

p62 -

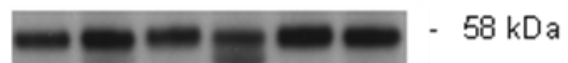

TDP-43 -

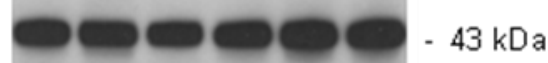

Tubulin -

$52 \mathrm{kDa}$

e

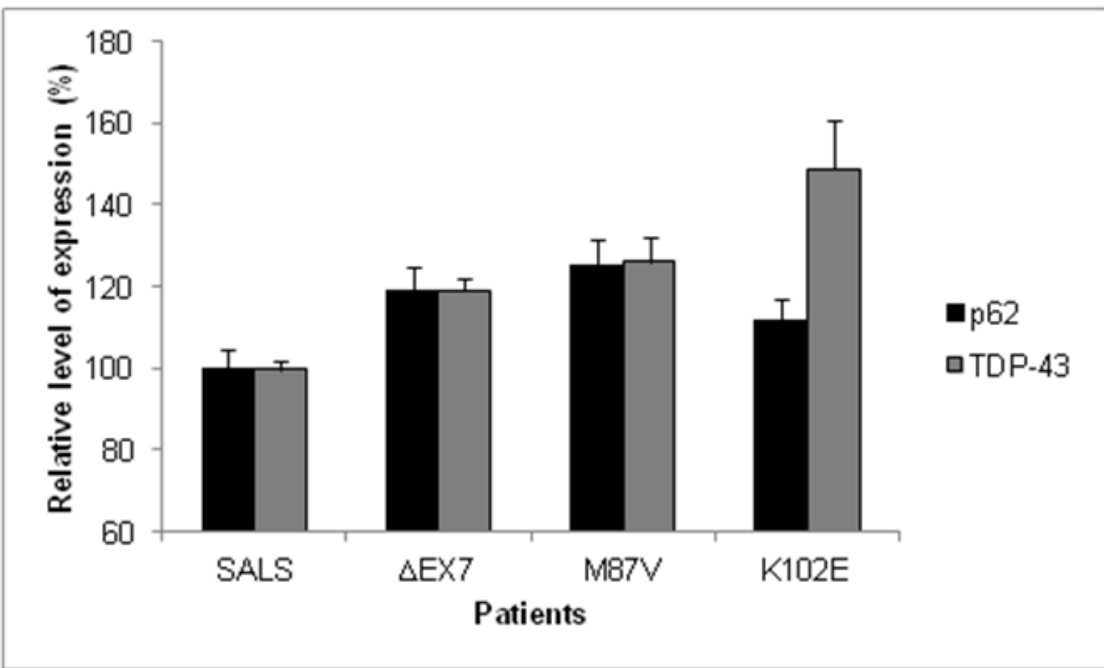

Fig. 2 

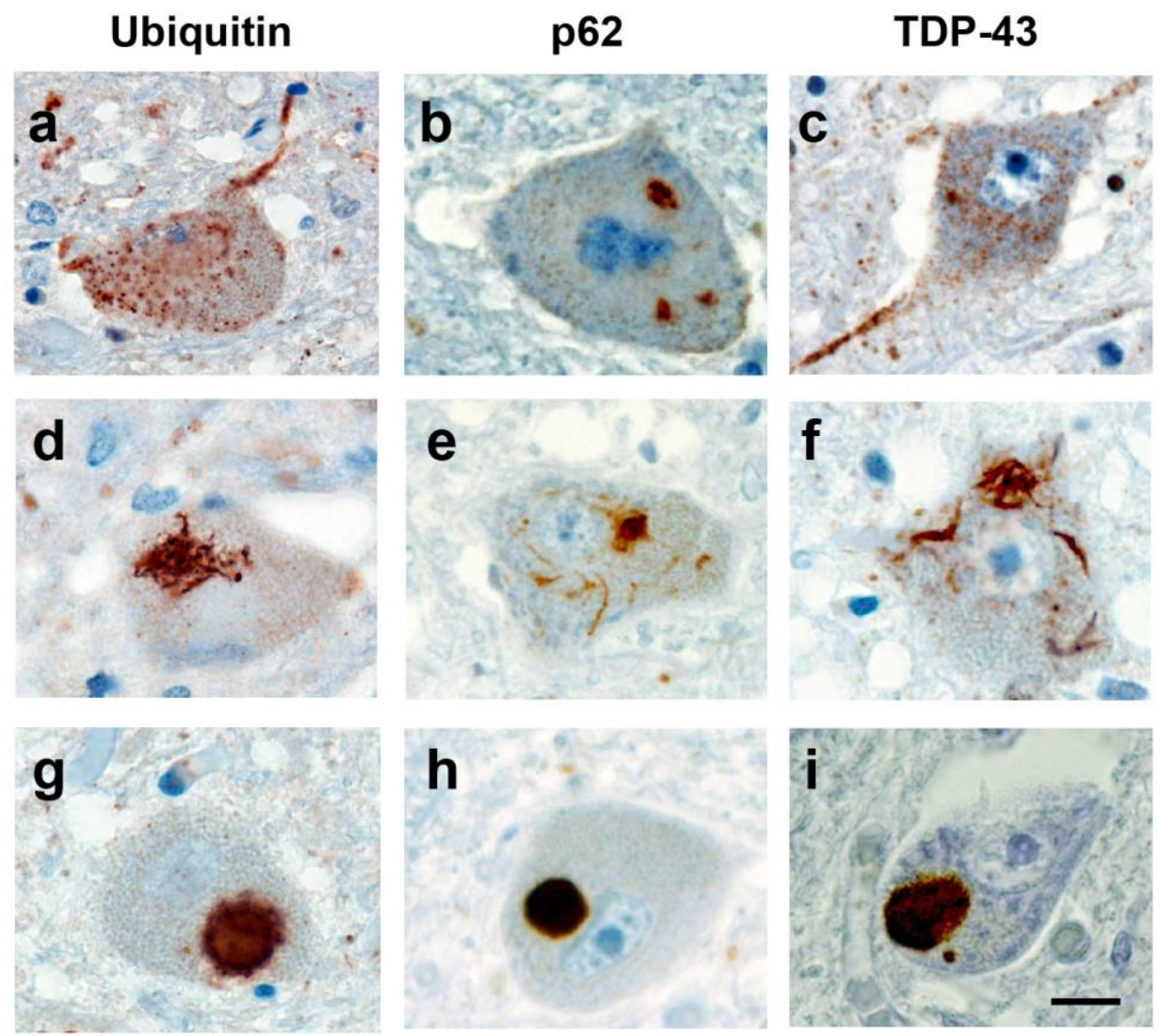

Fig 3. 


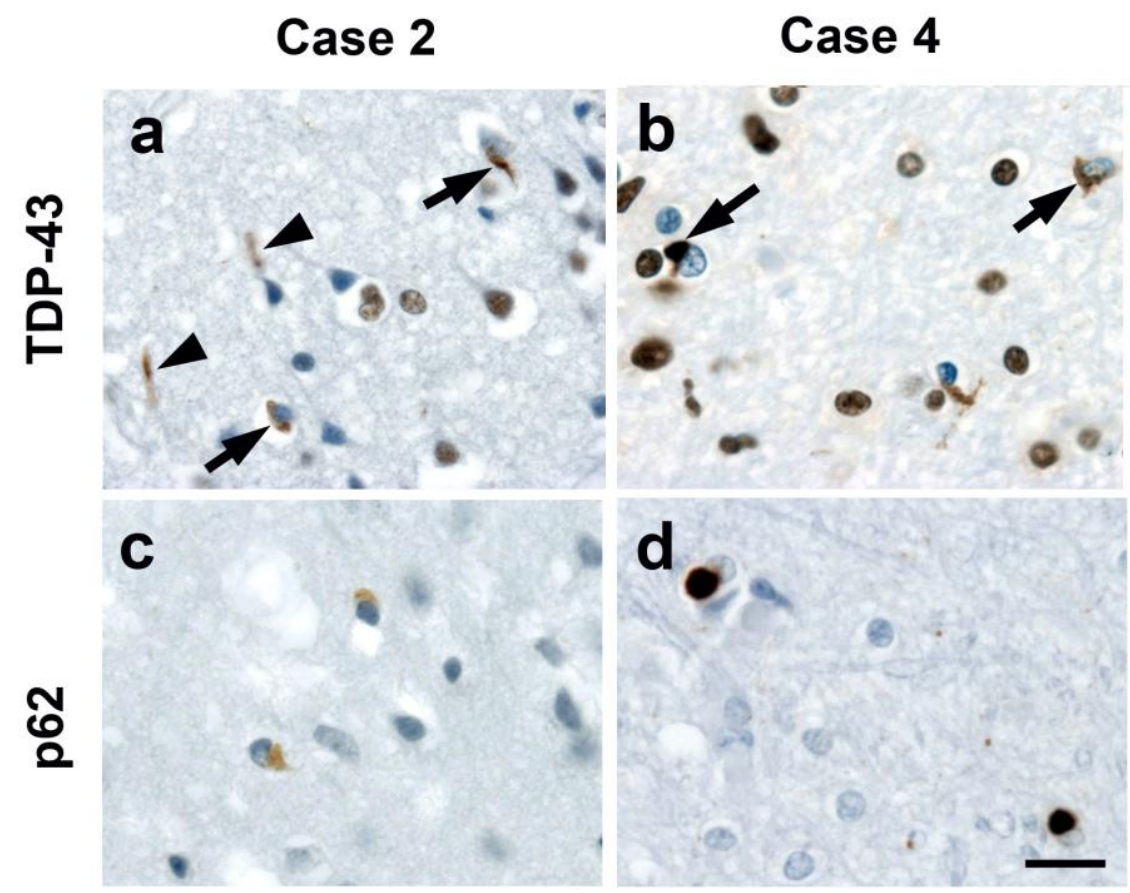

Fig. 4 